\title{
THE
}

\section{Beryllium isotopes in central Arctic Ocean sediments over the past 12.3 million years: Stratigraphic and paleoclimatic implications}

\author{
Martin Frank \\ Jan Backman \\ University of Rhode Island \\ Martin Jakobsson \\ University of Rhode Island \\ Kate Moran \\ University of Rhode Island \\ Matthew O'Regan \\ University of Rhode Island
}

See nextpage for additional authors

Terms of Use

All rights reserved under copyright.

\section{Citation/Publisher Attribution}

Frank, M., J. Backman, M. Jakobsson, K. Moran, M. O’Regan, J. King, B. A. Haley, P. W. Kubik, and D. GarbeScho"nberg (2008), Beryllium isotopes in central Arctic Ocean sediments over the past 12.3 million years: Stratigraphic and paleoclimatic implications, Paleoceanography, 23, PA1S02, doi:10.1029/2007PA001478 Available at: https://doi.org/10.1029/2007PA001478

This Article is brought to you for free and open access by the Graduate School of Oceanography at DigitalCommons@URI. It has been accepted for inclusion in Graduate School of Oceanography Faculty Publications by an authorized administrator of DigitalCommons@URI. For more information, please contact digitalcommons-group@uri.edu. 


\section{Authors}

Martin Frank, Jan Backman, Martin Jakobsson, Kate Moran, Matthew O'Regan, John W. King, Brian A. Haley, Peter W. Kubik, and Dieter Garbe-Schönberg 


\title{
Beryllium isotopes in central Arctic Ocean sediments over the past 12.3 million years: Stratigraphic and paleoclimatic implications
}

\author{
Martin Frank, ${ }^{1}$ Jan Backman, ${ }^{2}$ Martin Jakobsson, ${ }^{2}$ Kate Moran, ${ }^{3}$ Matthew O'Regan, ${ }^{4}$ \\ John King, ${ }^{4}$ Brian A. Haley, ${ }^{1}$ Peter W. Kubik, ${ }^{5}$ and Dieter Garbe-Schönberg ${ }^{6}$ \\ Received 29 April 2007; revised 18 October 2007; accepted 7 November 2007; published 20 February 2008
}

[1] The upper $200 \mathrm{~m}$ of the sediments recovered during IODP Leg 302, the Arctic Coring Expedition (ACEX), to the Lomonosov Ridge in the central Arctic Ocean consist almost exclusively of detrital material. The scarcity of biostratigraphic markers severely complicates the establishment of a reliable chronostratigraphic framework for these sediments, which contain the first continuous record of the Neogene environmental and climatic evolution of the Arctic region. Here we present profiles of cosmogenic ${ }^{10} \mathrm{Be}$ together with the seawater-derived fraction of stable ${ }^{9} \mathrm{Be}$ obtained from the ACEX cores. The down-core decrease of ${ }^{10} \mathrm{Be} /{ }^{9} \mathrm{Be}$ provides an average sedimentation rate of $14.5 \pm 1 \mathrm{~m} / \mathrm{Ma}$ for the uppermost $151 \mathrm{~m}$ of the ACEX record and allows the establishment of a chronostratigraphy for the past $12.3 \mathrm{Ma}$. The age-corrected ${ }^{10} \mathrm{Be}$ concentrations and ${ }^{10} \mathrm{Be} /{ }^{9} \mathrm{Be}$ ratios suggest the existence of an essentially continuous sea ice cover over the past $12.3 \mathrm{Ma}$.

Citation: Frank, M., J. Backman, M. Jakobsson, K. Moran, M. O’Regan, J. King, B. A. Haley, P. W. Kubik, and D. Garbe-Schönberg (2008), Beryllium isotopes in central Arctic Ocean sediments over the past 12.3 million years: Stratigraphic and paleoclimatic implications, Paleoceanography, 23, PA1S02, doi:10.1029/2007PA001478.

\section{Introduction}

[2] Until 2004, the Cretaceous and Cenozoic paleoceanographic and climatological evolution of the Arctic region had been inaccessible with the exception of a few unlithified sediment sections of late Cretaceous and Eocene age from the Alpha Ridge, which had been exposed by erosion. These sediments contained abundant siliceous microfossils and high percentages of organic carbon indicating completely different environmental conditions and surface temperatures of polar waters reaching $15^{\circ}-20^{\circ} \mathrm{C}$ [Delagnese and Clark, 1994; Jenkyns et al., 2004]. In 2004 the IODP Arctic Coring Expedition (Leg 302) penetrated $428 \mathrm{~m}$ into the sediments of the central Arctic Lomonosov Ridge [Moran et al., 2006; Backman et al., 2008]. These sediments documented even higher temperatures reaching $23^{\circ} \mathrm{C}$ during the Paleocene/Eocene thermal maximum at $55 \mathrm{Ma}$ [Sluijs et al., 2006]. The Neogene upper $\sim 200 \mathrm{~m}$ section of the ACEX record is separated from the Eocene by a 26 Ma hiatus [Moran et al., 2006; Backman et al., 2008].

\footnotetext{
${ }^{1}$ Leibniz Institute of Marine Sciences (IFM-GEOMAR), Kiel, Germany. ${ }^{2}$ Department of Geology and Geochemistry, Stockholm University, Stockholm, Sweden.

${ }^{3}$ Graduate School of Oceanography and Department of Ocean Engineering, University of Rhode Island, Narragansett, Rhode Island, USA.

${ }^{4}$ Graduate School of Oceanography, University of Rhode Island, Narragansett, Rhode Island, USA.

${ }^{5}$ Paul Scherrer Institute, Institute of Particle Physics, ETH-Zurich, Zurich, Switzerland.

${ }^{6}$ Institute of Geosciences, University of Kiel, Kiel, Germany.
}

Copyright 2008 by the American Geophysical Union. 0883-8305/08/2007PA001478
The Neogene sediments are similar in lithology to Quaternary Arctic Ocean sediments in that they consist almost exclusively of detrital sediments and, with the exception of a few occurrences of agglutinated foraminifera and dinoflagellate cysts, are essentially barren of biogenic materials [Backman et al., 2008; O'Regan et al., 2008], which renders the extraction of paleoceanographic and paleoclimatic information as well as reliable dating of this part of the record a challenge. Here we apply beryllium $(\mathrm{Be})$ isotopes for both the establishment of a chronostratigraphic framework and for the extraction of information on the Neogene paleoenvironment of the central Arctic Ocean.

[3] Cosmogenic ${ }^{10} \mathrm{Be}$ is produced by spallation of oxygen and nitrogen atoms through interaction with primary and secondary galactic cosmic rays in the upper atmosphere. The half-life of ${ }^{10} \mathrm{Be}\left(\mathrm{T}_{1 / 2}\right)$ was determined to be $1.51 \pm$ $0.06 \mathrm{Ma}$ [Hofmann et al., 1987] but there is an ongoing debate on the correct value. Recent suggestions are in the range of 1.34 to $1.36 \mathrm{Ma}$ [Fink and Smith, 2007; Nishiizumi et al., 2007]. There are, however, some inherent problems with these recent results that need to be resolved [Fink and Smith, 2007], which is why there is no general agreement on a different value as yet. We therefore kept using $1.51 \mathrm{Ma}$ in this study. The global average atmospheric production rate of ${ }^{10} \mathrm{Be}$ was estimated at $1.21 \pm 0.26 \times 10^{6}$ atoms $\mathrm{cm}^{-2} \mathrm{a}^{-1}$ from precipitation collections [Monaghan et al., 1985/1986]. Depending on the applied methods, such as theoretical calculations [cf. Lal and Peters, 1967], ice core deposition rates [cf. Raisbeck et al., 1978], lake sediments [cf. Brown et al., 1987] there is a range of other estimates between $0.1 \times 10^{6}$ atoms $\mathrm{cm}^{-2} \mathrm{a}^{-1}$ (from deposition rates in ice cores [Raisbeck et al., 1978]) and $1.6 \times 10^{6}$ atoms cm ${ }^{-2} \mathrm{a}^{-1}$ (from precipitation collection [Somayajulu et al., 1984]). 
The absolute value of the present-day production rate is, however, not relevant for this contribution. Although the highest production rates occur at high latitudes owing to the weak shielding of the cosmic ray flux by the Earth's magnetic field, the highest ${ }^{10} \mathrm{Be}$ fluxes to the Earth's surface are observed in midlatitudes owing to the maximum in stratospheric-tropospheric exchange [Lal and Peters, 1967; Field et al., 2006]. The ${ }^{10} \mathrm{Be}$ is ultimately transferred from the atmosphere to the Earth's surface by precipitation and dry deposition. In the ocean, the spatial variability of ${ }^{10} \mathrm{Be}$ flux to the surface of the Earth is efficiently homogenized through water mass mixing. The stable isotope ${ }^{9} \mathrm{Be}$ is a trace component in all continental rocks, which is released by weathering and transferred to the ocean predominantly via rivers. Despite a study suggesting that a large fraction of the riverine Be flux is immobilized in estuaries and does not reach the open ocean [Kusakabe et al., 1991] it is likely that the riverine transport of dissolved ${ }^{9} \mathrm{Be}$, together with ${ }^{10} \mathrm{Be}$ originating from precipitation on the continents, is a major source of Be in the ocean. In the case of the Arctic Ocean, the importance of riverine inputs has recently been confirmed by clear evidence that a significant amount of the Be supplied by Siberian Rivers is in fact transported across the wide shelf areas to surface waters of the central Arctic basin (M. Frank et al., manuscript in preparation, 2008). Additional sources of ${ }^{9} \mathrm{Be}$ are the partial dissolution of particulate material supplied by rivers or by eolian transport. The average ${ }^{10} \mathrm{Be}$ residence time in the ocean is 500-1000 years resulting in relatively homogenous ${ }^{10} \mathrm{Be}$ concentrations in Atlantic deep waters of $800-1000$ atoms/g and up to 2000 atoms/g in the deep Pacific [Kusakabe et al., 1987, 1990; Measures et al., 1996]. This is a function of ${ }^{10} \mathrm{Be}$ being released by remineralization and desorption processes and being added to deep waters as they age along the deep pathways of the global thermohaline circulation. ${ }^{10} \mathrm{Be}$ is particle reactive, which is documented by its distinct depletion in oceanic surface waters and its systematic enrichment at depth [Kusakabe et al., 1987; Ku et al., 1990]. Because the residence time of ${ }^{10} \mathrm{Be}$ allows its advection over large distances, ${ }^{10} \mathrm{Be}$ is subject to a process called boundary scavenging, which describes the advective transfer of ${ }^{10} \mathrm{Be}$ from areas of low particulate fluxes to high particle flux areas, where it is deposited in excess of its production rate [Anderson et al., 1990]. If mixing and residence times of water masses are short relative to the residence time, ${ }^{10} \mathrm{Be}$ is a useful quasiconservative tracer for water mass mixing, at least on ocean basin scales. [cf. Measures et al., 1996; Frank et al., 2002]. In the low particle flux environment of the Arctic Ocean, the use of ${ }^{10} \mathrm{Be}$ as a tracer for surface water processes such as riverine inputs and sea ice melting is therefore possible (M. Frank et al., manuscript in preparation, 2008). Owing to the low particle fluxes and the sluggish exchange with the Atlantic Ocean reflected by ${ }^{14} \mathrm{C}$-based residence age estimates of the Arctic deep water masses on the order of 150-300 years in the Eurasian basin and 350-450 years in the Canada and Makarov basins [e.g., Schlosser et al., 1995], the modern Arctic deep water ${ }^{10} \mathrm{Be}$ content, as well as the ${ }^{10} \mathrm{Be} /{ }^{9} \mathrm{Be}$ ratio below about $500 \mathrm{~m}$ water depth, are essentially homogenous at values of $500 \pm 100 \mathrm{at} / \mathrm{g}$ and
$7 \times 10^{-8}$, respectively [Strobl et al., 1999; M. Frank et al., manuscript in preparation, 2008].

[4] The ${ }^{10} \mathrm{Be}$ has been used to constrain the stratigraphy of Late Quaternary sediments from the northern North Atlantic and the Arctic Ocean. This approach was developed for sediments that do not contain a lot of biogenic material or consist exclusively of detrital material. The stratigraphic information was derived from correlations of the pattern of variations in ${ }^{10} \mathrm{Be}$ concentrations [Eisenhauer et al., 1994; Spielhagen et al., 1997; Aldahan et al., 1997]. These variations were caused by pronounced increases in accumulation of Ice Rafted Debris (IRD), mainly during glacial periods, which caused an increase in sedimentation rates and thus a dilution of the ${ }^{10} \mathrm{Be}$ concentrations in the sediments. In the glacial Arctic Ocean this effect was amplified by an enhanced and extended sea ice cover, which prevented the atmospheric ${ }^{10} \mathrm{Be}$ fallout from reaching the Arctic surface waters, thus also decreasing the flux of ${ }^{10} \mathrm{Be}$ arriving at the Arctic sediments. Instead, sea ice transported a large fraction of the ${ }^{10} \mathrm{Be}$ out of the Arctic Ocean through the Fram Strait into the North Atlantic [Eisenhauer et al., 1994]. The combination of these two effects led to pronounced minima of ${ }^{10} \mathrm{Be}$ concentrations (approaching detection limits) in the glacial periods of the Late Quaternary.

[5] In the ACEX record, as well as in shorter piston cores from proximal sites on the Lomonosov Ridge (PS-2185; 96/ $12-1 \mathrm{pc})$, the pronounced variability in coarse fraction content (>63 um) [Spielhagen et al., 1997, 2004; Jakobsson et al., 2001; Darby et al., 2006] and ${ }^{10} \mathrm{Be}$ concentrations [Spielhagen et al., 1997, 2004] significantly decreases below 3-5 $\mathrm{m}$ depth. The first significant increase in coarse fraction content (occurring at $\sim 4.70 \mathrm{mcd}$ in the ACEX record) has been attributed to a massive influx of icebergs from the Barents-Kara shelf during Marine Isotope Stage (MIS) 6 [Jakobsson et al., 2001; Spielhagen et al., 2004]. Sites on the Lomonosov Ridge shallower than the ACEX cores (above $1000 \mathrm{~m}$ water depth) even experienced erosion, most likely by a grounded ice sheet or by a massive armada of icebergs during the MIS 6 glaciation [Jakobsson et al., 2001; Polyak et al., 2001; Kristoffersen et al., 2004]. Below the major MIS 6 coarse-grained layer serving as a stratigraphic marker in the ACEX record, as well as cores 96/12-PC and PS-2185, grain size variations are less pronounced. Low ${ }^{10} \mathrm{Be}$ concentrations and ${ }^{10} \mathrm{Be}$ fluxes similar to glacial stages in the sections older than MIS 6 clearly document that sea ice cover exerted a strong control on ${ }^{10} \mathrm{Be}$ deposition.

[6] Initial attempts to interpret an apparent overall decrease of the ${ }^{10} \mathrm{Be}$ concentrations with depth in the upper $5-10 \mathrm{~m}$ of the microfossil-poor Arctic sediments in terms of radioactive decay of ${ }^{10} \mathrm{Be}$, such as in core PS 2185 from the Lomonosov Ridge, resulted in very low average sedimentation rates on the order of $0.5 \mathrm{~cm} / \mathrm{ka}$ [Spielhagen et al., 1997]. These estimates were consistent with low sedimentation rates obtained by ${ }^{14} \mathrm{C}$ dating for the uppermost $25 \mathrm{~cm}$ in a number of central Arctic sediment cores [NørgaardPedersen et al., 1998]. For sediments deposited prior to the Holocene, these rates were later shown to be unrealistically low and were independently constrained to be quite variable 


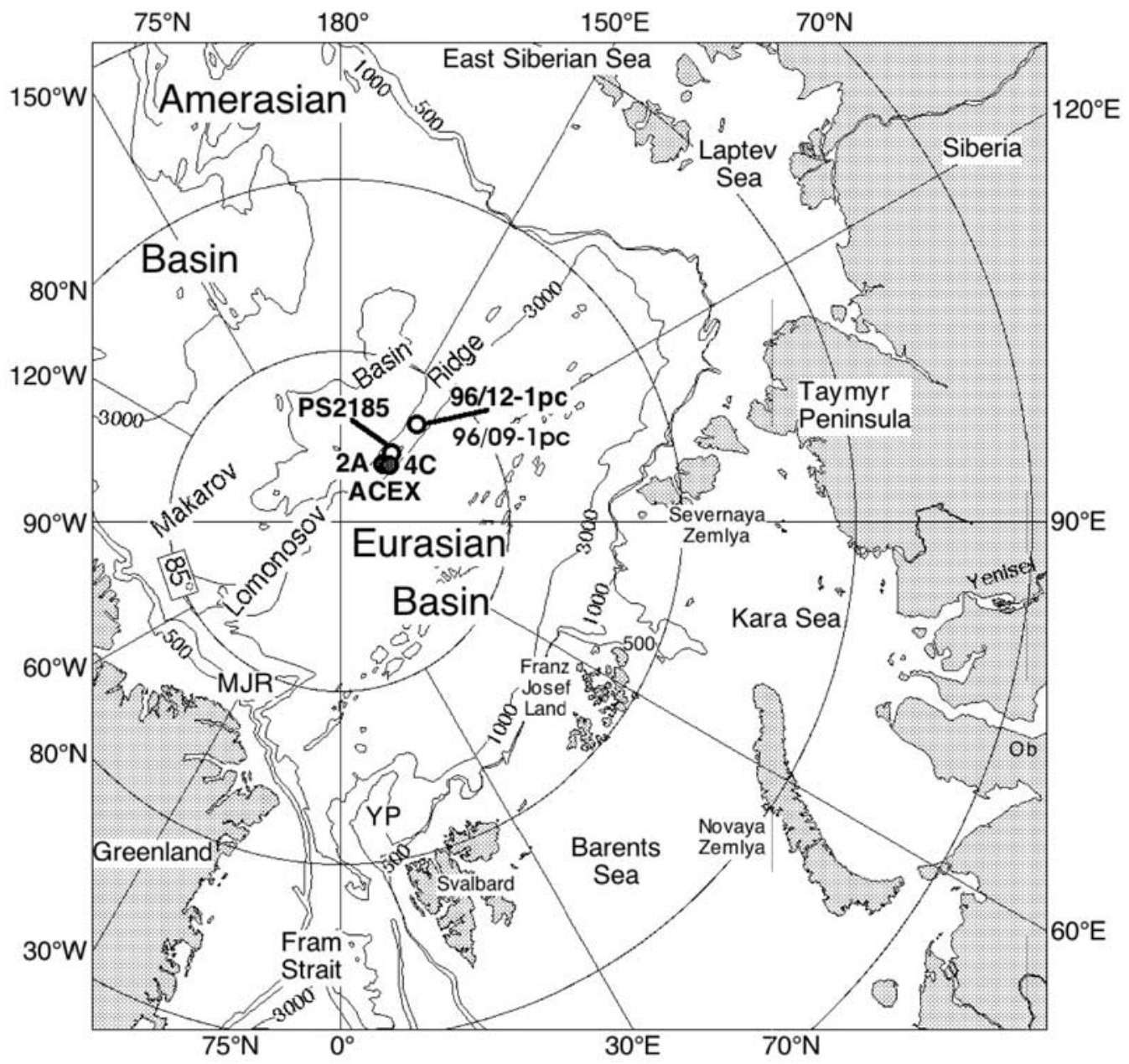

Figure 1. Bathymetric map of the eastern and central Arctic Ocean with the locations of the sediment cores of this study and of previous studies discussed here. MJR denotes the Morris Jesup Rise, and YP denotes the Yermak Plateau.

but on average on the order of $1.8 \mathrm{~cm} / \mathrm{ka}$ on the Lomonosov Ridge [Jakobsson et al., 2000, 2001; Spielhagen et al., 2004; Backman et al., 2004]. This evidence strongly suggested that the $30-40 \%$ down-core decrease of the maxima in ${ }^{10} \mathrm{Be}$ concentration was caused by pronounced variability of sedimentary parameters in the upper $5 \mathrm{~m}$ and a more continuous sea ice cover below. The reduced variability in sedimentary parameters suggests that relatively constant ${ }^{10} \mathrm{Be}$ concentrations are expected below $\sim 4.70 \mathrm{mcd}$, allowing accurate dating of the ACEX sediments via decay of ${ }^{10} \mathrm{Be}$, similar to an early study by Bourlès et al. [1989] on a red clay sediment core from the central Pacific Ocean. This method was shown to provide reliable average sedimentation rates for long sedimentary sequences. However, the method was not applied at many other locations than the one in the central Pacific Ocean, because in sediments with regular pelagic sedimentation rates, abundant microfossils, biostratigraphy and oxygen isotope stratigraphy provide a much more differentiated and better resolved picture of the late Neogene sedimentation. In addition the variability of the ${ }^{10} \mathrm{Be}$ concentrations in such sediments is generally very high causing too much scatter for accurate dating [e.g., Aldahan and Possnert, 2000].

[7] In this study we establish a chronology for the upper $151 \mathrm{~m}$ of the ACEX sediment cores based on the radioactive decay of ${ }^{10} \mathrm{Be}$. From a shallower location further toward the Siberian Continental Margin on the Lomonosov Ridge (Figure 1), which has experienced ice erosion during MIS 6 , we apply ${ }^{10} \mathrm{Be}$ dating to estimate the thickness of the sediment cover that was removed by the grounded ice. Finally we investigate oceanographic and paleomagnetic influences on the ${ }^{10} \mathrm{Be}$ deposition in the ACEX core and based on the ${ }^{10} \mathrm{Be}$ data we provide evidence for the stability of the depositional environment above the Lomonosov Ridge over the past $12.3 \mathrm{Ma}$.

\section{Material and Methods}

[8] The upper $200 \mathrm{~m}$ of the ACEX (IODP Leg 302) sediments (a composite of Holes 2A: $139^{\circ} 21.901^{\prime} \mathrm{E}$, $87^{\circ} 55.271^{\prime} \mathrm{N}, 1209 \mathrm{~m}$ water depth, and $4 \mathrm{C}: 136^{\circ} 11.381^{\prime} \mathrm{E}$, $87^{\circ} 52.065^{\prime} \mathrm{N}, 1288 \mathrm{~m}$ water depth; Figure 1) are almost completely barren of biostratigraphic marker species and only allow a few, poorly resolved age/depth constraints 
Table 1. The ${ }^{10} \mathrm{Be}$ and ${ }^{9} \mathrm{Be}$ Data

\begin{tabular}{|c|c|c|c|c|c|}
\hline Sample Description & Depth, med & Age, Ma & $\begin{array}{c}{ }^{10} \mathrm{Be}, \times 10^{7} \text { atoms } / \mathrm{g}, \\
\pm 1 \sigma \text { S.E. }\end{array}$ & ${ }^{9} \mathrm{Be}, \mathrm{ppb}$ & $\begin{array}{c}{ }^{10} \mathrm{Be} /{ }^{9} \mathrm{Be}, \\
\times 10^{-9}, \pm 1 \sigma \text { S.E }\end{array}$ \\
\hline \multicolumn{6}{|c|}{ ACEX (Composite) } \\
\hline $302 / 4 \mathrm{C} / 1 / 2 \mathrm{~W} / 80-82$ & 2.31 & 0.07 & $22.55 \pm 0.68$ & 97 & $38.49 \pm 1.17$ \\
\hline $302 / 4 \mathrm{C} / 2 / 1 \mathrm{~W} / 130-132$ & 4.64 & 0.19 & $84.69 \pm 2.55$ & 164 & $85.57 \pm 2.57$ \\
\hline $302 / 4 \mathrm{C} / 2 / 4 \mathrm{~W} / 86-88$ & 8.71 & 0.60 & $20.15 \pm 0.61$ & 97 & $34.45 \pm 1.05$ \\
\hline $302 / 4 \mathrm{C} / 3 / 2 \mathrm{~W} / 123-125$ & 10.61 & 0.73 & $18.85 \pm 0.61$ & 100 & $31.35 \pm 1.02$ \\
\hline $302 / 4 \mathrm{C} / 4 / 2 \mathrm{~W} / 22-25$ & 14.31 & 0.99 & $18.94 \pm 0.69$ & 77 & $41.08 \pm 1.50$ \\
\hline $302 / 4 \mathrm{C} / 4 / 3 \mathrm{~W} / 60-62$ & 16.19 & 1.12 & $15.46 \pm 0.50$ & 79 & $32.37 \pm 1.05$ \\
\hline $302 / 2 \mathrm{~A} / 5 / 2 \mathrm{~W} / 0-2$ & 21.93 & 1.52 & $14.18 \pm 0.50$ & 142 & $16.64 \pm 0.59$ \\
\hline $302 / 2 \mathrm{~A} / 6 / 1 \mathrm{~W} / 24-26$ & 24.86 & 1.69 & $19.23 \pm 0.58$ & 150 & $21.25 \pm 0.64$ \\
\hline $302 / 2 \mathrm{~A} / 7 / 2 \mathrm{~W} / 24-26$ & 30.86 & 2.13 & $13.41 \pm 0.49$ & 167 & $13.33 \pm 0.49$ \\
\hline $302 / 2 \mathrm{~A} / 8 / 2 \mathrm{~W} / 70-72$ & 35.62 & 2.46 & $9.65 \pm 0.35$ & 208 & $7.70 \pm 0.28$ \\
\hline $302 / 2 \mathrm{~A} / 9 / 2 \mathrm{~W} / 56-58$ & 39.12 & 2.70 & $8.30 \pm 0.30$ & 131 & $10.52 \pm 0.38$ \\
\hline $302 / 2 \mathrm{~A} / 10 / 2 \mathrm{~W} / 70-72$ & 43.76 & 3.02 & $5.96 \pm 0.28$ & 129 & $7.66 \pm 0.37$ \\
\hline $302 / 2 \mathrm{~A} / 11 / 2 \mathrm{~W} / 70-72$ & 48.19 & 3.33 & $4.73 \pm 0.25$ & 124 & $6.35 \pm 0.34$ \\
\hline $302 / 2 \mathrm{~A} / 12 / 3 \mathrm{~W} / 32-34$ & 52.84 & 3.65 & $5.44 \pm 0.23$ & 157 & $5.76 \pm 0.24$ \\
\hline $302 / 2 \mathrm{~A} / 14 / 1 \mathrm{~W} / 80-82$ & 60.80 & 4.20 & $4.00 \pm 0.19$ & 132 & $5.04 \pm 0.24$ \\
\hline $302 / 2 \mathrm{~A} / 15 / 1 \mathrm{~W} / 30-32$ & 65.30 & 4.51 & $3.33 \pm 0.16$ & 113 & $4.88 \pm 0.23$ \\
\hline $302 / 2 \mathrm{~A} / 16 / 2 \mathrm{~W} / 70-72$ & 71.54 & 4.94 & $3.67 \pm 0.17$ & 148 & $4.11 \pm 0.19$ \\
\hline $302 / 2 \mathrm{~A} / 17 / 1 \mathrm{~W} / 108-110$ & 75.08 & 5.19 & $2.84 \pm 0.14$ & 106 & $4.45 \pm 0.22$ \\
\hline $302 / 2 \mathrm{~A} / 18 / 2 \mathrm{~W} / 2-4$ & 79.47 & 5.49 & $6.52 \pm 0.21$ & 153 & $7.08 \pm 0.23$ \\
\hline $302 / 2 \mathrm{~A} / 20 / 1 \mathrm{~W} / 70-72$ & 86.90 & 6.01 & $2.44 \pm 0.14$ & 133 & $3.05 \pm 0.17$ \\
\hline $302 / 2 \mathrm{~A} / 21 / 1 \mathrm{~W} / 78-80$ & 91.98 & 6.36 & $2.27 \pm 0.11$ & 131 & $2.88 \pm 0.14$ \\
\hline $302 / 2 \mathrm{~A} / 23 / 2 \mathrm{~W} / 70-72$ & 102.03 & 7.05 & $1.23 \pm 0.07$ & 114 & $1.79 \pm 0.10$ \\
\hline $302 / 2 \mathrm{~A} / 24 / 2 \mathrm{~W} / 70-72$ & 108.39 & 7.49 & $1.26 \pm 0.06$ & 142 & $1.48 \pm 0.07$ \\
\hline $302 / 2 \mathrm{~A} / 25 / 2 \mathrm{~W} / 70-72$ & 112.90 & 7.80 & $2.20 \pm 0.11$ & 147 & $2.48 \pm 0.12$ \\
\hline $302 / 2 \mathrm{~A} / 26 / 2 \mathrm{~W} / 56-58$ & 117.26 & 8.10 & $0.70 \pm 0.04$ & 145 & $0.81 \pm 0.05$ \\
\hline $302 / 2 \mathrm{~A} / 27 / 2 \mathrm{~W} / 70-72$ & 122.40 & 8.46 & $0.87 \pm 0.06$ & 183 & $0.79 \pm 0.06$ \\
\hline $302 / 2 \mathrm{~A} / 29 / 2 \mathrm{~W} / 70-72$ & 130.40 & 9.01 & $0.60 \pm 0.04$ & 161 & $0.62 \pm 0.04$ \\
\hline $302 / 2 \mathrm{~A} / 30 / 2 \mathrm{~W} / 78-80$ & 135.49 & 9.36 & $0.60 \pm 0.04$ & 167 & $0.60 \pm 0.04$ \\
\hline \multicolumn{6}{|l|}{ Hiatus } \\
\hline $302 / 2 \mathrm{~A} / 32 / 1 \mathrm{~W} / 74-76$ & 140.44 & 11.56 & $0.22 \pm 0.04$ & 163 & $0.22 \pm 0.04$ \\
\hline $302 / 2 \mathrm{~A} / 33 / 2 \mathrm{~W} / 78-80$ & 147.29 & 12.03 & $0.19 \pm 0.03$ & 141 & $0.22 \pm 0.03$ \\
\hline $302 / 2 \mathrm{~A} / 34 / 2 \mathrm{~W} / 78-80$ & 151.28 & 12.31 & $0.13 \pm 0.03$ & 156 & $0.14 \pm 0.03$ \\
\hline $302 / 4 \mathrm{~A} / 6 / 2 \mathrm{~W} / 72-74$ & 270.28 & & blank & & \\
\hline $302 / 4 \mathrm{~A} / 27 / 2 \mathrm{~W} / 68-70$ & 368.58 & & blank & & \\
\hline \multicolumn{6}{|c|}{$69 / 09-1 p c$} \\
\hline & 0.02 & & $69.81 \pm 2.10$ & & \\
\hline & 0.20 & & $57.20 \pm 1.72$ & & \\
\hline & 1.00 & & $82.17 \pm 3.05$ & & \\
\hline & 1.37 & & $71.56 \pm 2.15$ & & \\
\hline & 1.55 & & $116.30 \pm 3.50$ & & \\
\hline & 1.69 & & $35.14 \pm 1.42$ & & \\
\hline \multicolumn{6}{|l|}{ Hiatus } \\
\hline & 1.79 & & $3.26 \pm 0.19$ & & \\
\hline & 2.00 & & $2.58 \pm 0.18$ & & \\
\hline & 2.18 & & $2.24 \pm 0.15$ & & \\
\hline
\end{tabular}

[Moran et al., 2006; Backman et al., 2008]. A total of 31 samples of the upper $152 \mathrm{~m}$ of the ACEX sediment cores (Table 1) were taken for Be isotope analyses roughly every 5 $\mathrm{m}$. The samples were dried, homogenized, and subjected to an established procedure base on leaching with $6 \mathrm{M} \mathrm{HCl}$ for the extraction of ${ }^{10} \mathrm{Be}$ from marine sediments [Henken-Mellies et al., 1990; Frank et al., 1994]. For the measurement of the ${ }^{10} \mathrm{Be}$ concentration by isotope dilution a known amount of a ${ }^{9} \mathrm{Be}$ carrier was added prior to leaching and purification of the Be. The ${ }^{10} \mathrm{Be}$ concentrations were measured at the Zürich AMS facility of the Paul Scherrer Institute and the ETH Zürich, Switzerland. The ${ }^{10} \mathrm{Be} /{ }^{9} \mathrm{Be}$ ratios that were measured at the accelerator for determination of the ${ }^{10} \mathrm{Be}$ concentrations were normalized to the internal standard S555 with a nominal ${ }^{10} \mathrm{Be} /{ }^{9} \mathrm{Be}$ ratio of $95.5 \times 10^{-12}$. The $1 \sigma$ statistical uncertainties of individual ${ }^{10} \mathrm{Be}$ measurements take into account both the counting statistics of the ${ }^{10} \mathrm{Be}$ "events" and the repro- ducibility of repeated measurements, which were performed for each sample. In addition to these 31 samples, 2 samples from 270.28 and 368.68 mcd were included in order to constrain background ${ }^{10} \mathrm{Be}$ concentrations arising from potential contaminations during sample handling, which turned out to be indistinguishable from the chemistry blanks measured.

[9] The second core subject of this study, 96/09-1pc $\left(143^{\circ} 26.62^{\prime} \mathrm{E}, 86^{\circ} 24.87^{\prime} \mathrm{N}, 927 \mathrm{~m}\right.$ water depth, total recovery $270 \mathrm{~cm}$ ), was retrieved with the Swedish icebreaker Oden during the Arctic Ocean-96 expedition arranged by the Swedish Polar Research Secretariat [Backman et al., 1997]. This core experienced erosion by grounded ice during MIS 6, which is reflected by a hiatus of unknown duration at $170 \mathrm{~cm}$ core depth, clearly identifiable by sedimentological and physical parameters [Jakobsson et al., 2001]. In order to determine the duration of the hiatus, ${ }^{10} \mathrm{Be}$ concentrations were 


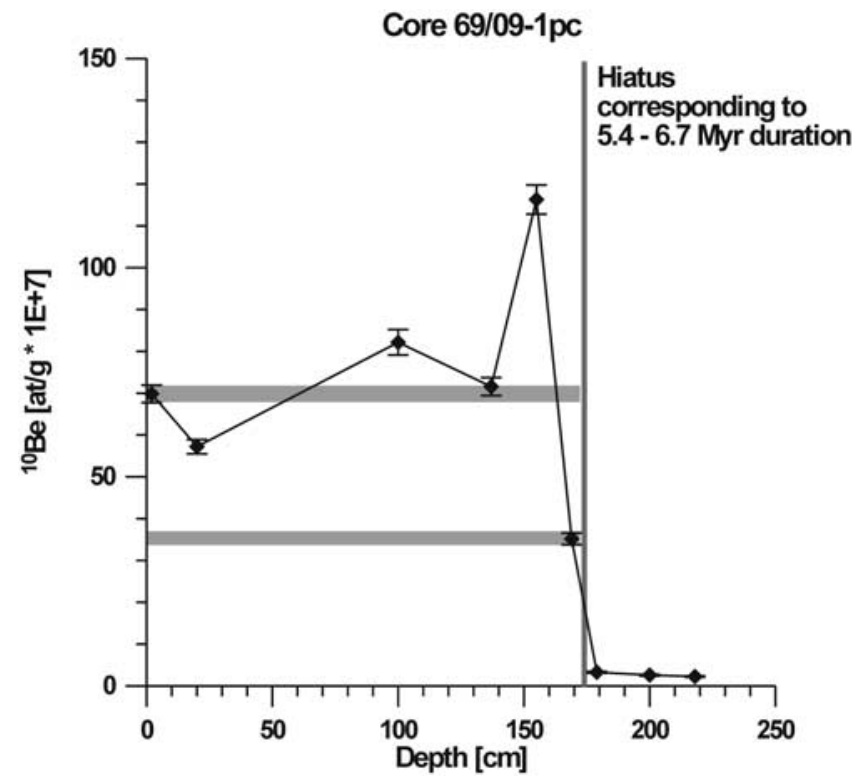

Figure 2. The ${ }^{10} \mathrm{Be}$ concentrations $\left(\times 10^{7}\right.$ atoms $\left./ \mathrm{g}\right)$ against depth in core 96/09-1pc (centimeters). Error bars denote the $1 \sigma$ statistical uncertainties of the AMS measurements. The vertical grey line denotes the depth of a hiatus caused by ice erosion identified previously on the basis of sedimentary parameters [Jakobsson et al., 2001]. The grey horizontal bars denote the average value and the lower limit for the

${ }^{10} \mathrm{Be}$ concentrations above the hiatus, which were applied to estimate durations of the hiatus of 5.4 and $6.7 \mathrm{Ma}$.

measured on a total of 9 samples distributed above and below the hiatus.

[10] For the ACEX core, concentrations of stable ${ }^{9}$ Be were extracted from the same sediment samples as those measured for ${ }^{10} \mathrm{Be}$ using a weak leaching procedure involving hydroxylamine hydrochloride [Bayon et al., 2002; Gutjahr et al., 2007]. This procedure is supposed to selectively dissolve the authigenic (bottom water water-derived) trace metal fraction from marine sediments located in thin early diagenetic ferromanganese coatings. The data were acquired at the ICPMS-Laboratory of the Institute of Geosciences, University of Kiel, using an AGILENT 7500cs ICP-MS instrument following established standard procedures [Garbe-Schönberg, 1993]. Repeat measurements of samples processed separately through the leaching procedure indicate a $1 \sigma$ reproducibility of $5 \%$. The ${ }^{10} \mathrm{Be} /{ }^{9} \mathrm{Be}$ values calculated from these data do not represent true seawater ratios because the ${ }^{10} \mathrm{Be}$ and ${ }^{9} \mathrm{Be}$ concentrations were not measured on aliquots of the same leaching solutions. The calculated ratios do serve, however, to eliminate dilution effects by short-term changes in sedimentation rates and changes in the grain size (IRD inputs) of the sediments.

\section{Results and Discussion}

3.1. Core 96/09-1pc: Estimation of Sediment Removal by Ice Erosion

[11] The ${ }^{10}$ Be concentrations above $170 \mathrm{~cm}$ of core $96 / 09$ $1 \mathrm{pc}$ vary between values of 35 and $116 \times 10^{7}$ at $/ \mathrm{g}$, which is the same range as observed in other central Arctic records [Spielhagen et al., 1997, 2004]. The lowest value of $35 \times$ $10^{7} \mathrm{at} / \mathrm{g}$ is found immediately above the hiatus and is very similar to the average value of the ACEX core (see below) and thus indicates similar sedimentation conditions. Below the hiatus, the ${ }^{10} \mathrm{Be}$ concentrations drop to values between 3.2 and $2.2 \times 10^{7} \mathrm{at} / \mathrm{g}$ (Figure 2). The difference between the ${ }^{10} \mathrm{Be}$ concentrations above and below the hiatus corresponds to the time it took to accumulate the sediments that during MIS 6 were removed by ice erosion, assuming that the sedimentation rates and thus the dilution effects for the

${ }^{10} \mathrm{Be}$ concentrations were the same before and after the erosional event. This may not have been exactly the case because sedimentation conditions may have changed during the period of time corresponding to the hiatus, but it is the best estimate based on the available data. We used a value of $3 \times 10^{7}$ at $/ \mathrm{g}$ below the hiatus and two different initial ${ }^{10} \mathrm{Be}$ concentrations above the hiatus for the calculation of the timing of the hiatus: (case a) the average value for the upper $170 \mathrm{~cm}$ of the core $\left(\sim 70 \times 10^{7} \mathrm{at} / \mathrm{g}\right)$ and (case b) the data point immediately above the hiatus (Figure 2). The resulting duration of the hiatus is $6.7 \mathrm{Ma}$ in case a and 5.4 $\mathrm{Ma}$ in case b. In view of its position directly above the hiatus and the similarity to the average (decay-corrected)

${ }^{10} \mathrm{Be}$ concentrations of the ACEX core we regard case $b$ to be more realistic than case a. This implies that the age of 5.4 Ma immediately below the hiatus in core 96/09-1 pc corresponds to about $80 \mathrm{mcd}$ in the ACEX core. Consequently, if the sedimentation rates at the site of 96/09-1pc were similar to the ACEX core, then $\sim 80$ m of previously deposited sediment were removed by ice erosion. Subbottom profiles and side scan data acquired during the SCICEX 1999 expedition with US nuclear submarine Hawkbill show that these eroded sediments were accumulated in the Makarov Basin [Jakobsson et al., 2008]. Erosion of as much as $80 \mathrm{~m}$ of the ridge stratigraphy corresponds to approximately double the previous estimations of 35-37 m by Jakobsson et al. [2001], which were based on shear strength measurements and consolidation tests of sediment samples below the hiatus. Only if the sedimentation rates at the location of core 96/09-1pc were about half those of the ACEX core (i.e., on the order of $7 \mathrm{~m} / \mathrm{Ma}$ ), for which there is no independent evidence, the previous estimations would apply. Despite these uncertainties on the exact thickness, the ${ }^{10} \mathrm{Be}$ data provide clear and independent evidence for the removal of large amounts of sediment by ice erosion from sites shallower than $1000 \mathrm{~m}$ on the Lomonosov Ridge corresponding to at least $5 \mathrm{Ma}$ of sedimentation history.

\subsection{Dating of the ACEX Sediments}

[12] The ${ }^{10} \mathrm{Be}$ concentration of $22.5 \times 10^{7} \mathrm{at} / \mathrm{g}$ of the uppermost data point at $2.31 \mathrm{mcd}$ is within the range of the glacial ${ }^{10} \mathrm{Be}$ concentrations in other Late Quaternary sediment cores from the Arctic Ocean [Spielhagen et al., 1997, 2004; Nowaczyk et al., 2001] indicating similar sedimentation conditions. Within some scatter, the ${ }^{10} \mathrm{Be}$ concentrations show a clear exponential decrease with depth (Figure 3). An exponential fit to the data between 2.3 and 135.5 mcd results in a correlation coefficient $\left(r^{2}\right)$ 


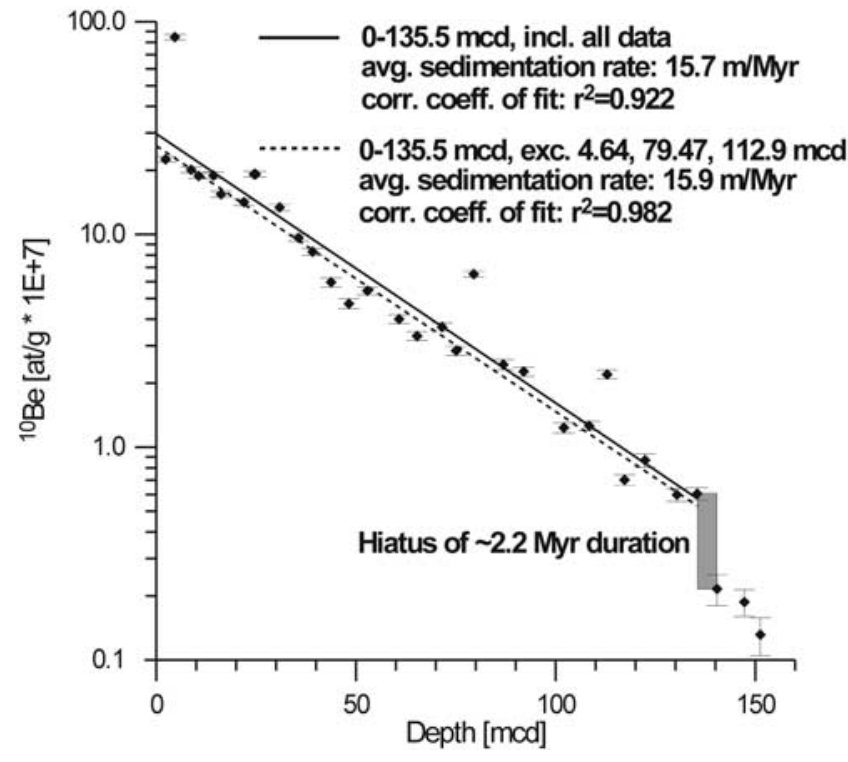

Figure 3. The ${ }^{10} \mathrm{Be}$ concentrations $\left(\times 10^{7}\right.$ atoms $\left./ \mathrm{g}\right)$ against depth in the ACEX core (in meters composite depth (mcd)). Error bars denote the $1 \sigma$ statistical uncertainties of the AMS measurements. The solid line represents an exponential fit to all data of the upper $135.5 \mathrm{~m}$, whereas the dashed line represents a fit excluding significantly higher values at 4.64, 79.47, and $112.9 \mathrm{mcd}$. The correlation coefficients $\left(\mathrm{r}^{2}\right)$ are 0.922 and 0.982 , respectively. The average sedimentation rates obtained by the two fits are essentially identical. The grey bar between 135.5 and $140.4 \mathrm{mcd}$ indicates the presence of a hiatus of about 2.2 Ma duration.

of 0.922 and an average sedimentation rate of $15.7 \mathrm{~m} / \mathrm{Ma}$. The uncertainty estimated for this sedimentation rate is on the order of $\pm 1 \mathrm{~m} / \mathrm{Ma}$ considering the uncertainty of the halflife [Hofmann et al., 1987] and the scatter of the data, but does not include the additional uncertainty introduced by a potentially different half-life of ${ }^{10} \mathrm{Be}$ [Fink and Smith, 2007; Nishiizumi et al., 2007]. In view of potential short-term changes in sedimentation, such as pulses of IRD supply, and the superimposed variability of the ${ }^{10} \mathrm{Be}$ production rate, this is already a well-constrained result and suggests in turn that the sedimentation conditions must have been quite invariable for this interval in the core. There are, however, three distinct maximum values far above the fit at 4.64, 79.47, and $112.9 \mathrm{mcd}$, which may reflect sedimentation conditions similar to interglacial stages allowing for larger amounts of ${ }^{10} \mathrm{Be}$ to be transferred to the sediments. Comparison with the late Quaternary high-resolution ${ }^{10} \mathrm{Be}$ record of nearby sediment core PS2185 on the Lomonosov Ridge [Spielhagen et al., 1997, 2004] suggests that there are most likely also sections with higher ${ }^{10} \mathrm{Be}$ concentrations in the interglacial sections of the uppermost 3-4 $\mathrm{m}$ of the ACEX core, which were not captured by our coarse resolution sampling (see also section 3.4 for further discussion). Significant deviations toward low values were not found. Omitting those three depths from the fitting procedure (Figure 3$)$, the correlation coefficient is even higher $\left(r^{2}=\right.$
0.982 ) whereas the resulting sedimentation rate is essentially the same $(15.9 \mathrm{~m} / \mathrm{Ma})$.

[13] Between 135.5 and $140.4 \mathrm{mcd}$, a marked step in the ${ }^{10} \mathrm{Be}$ concentrations is observed, which either corresponds to a drop in sedimentation rates to values as low as $2.25 \mathrm{~m} / \mathrm{Ma}$, which is unlikely in view of the invariable sediment composition across this section, or to a hiatus with a duration of $\sim 2.2 \mathrm{Ma}$ (Figure 3 ). The lowermost three data points can again be fitted, within their already relatively large statistical uncertainties, by a line with a slope corresponding to the same sedimentation rate as above $135.5 \mathrm{mcd}$. On the basis of the information on the sedimentation rate and the hiatus derived above, this results in ages of 8.7 Ma at $135.5 \mathrm{~m}$ depth above the hiatus and 11.6 Ma at the deepest reliable data point at $151.3 \mathrm{mcd}$.

[14] To reduce the scatter of the down-core decrease in the ${ }^{10} \mathrm{Be}$ data and to eliminate potential major pulses of coarse grained material or sudden changes in sedimentation rate, we normalized the ${ }^{10} \mathrm{Be}$ concentrations to the sand and clay contents of the same sample depths. This normalization (not shown), did not further reduce the already relatively small scatter or improve the fit. The variability in sand and clay content is generally small for the depths in core nearest to our samples (varying between 7 and $18 \%$ for sand content and $28 \%$ and $40 \%$ for clay), which suggests, in accordance with the conclusion above, that the sedimentation conditions did not change a lot during the period covered by the section between 5 and 150 mcd of the ACEX core and that the ${ }^{10}$ Be variability was not caused by major changes in sedimentary parameters.

[15] It might be argued that the leaching method we applied instead of a total dissolution of the samples did not release all the seawater-derived ${ }^{10} \mathrm{Be}$. Clearly all this ${ }^{10} \mathrm{Be}$ is either adsorbed to particles or contained within early diagenetic $\mathrm{Mn}-\mathrm{Fe}$ coatings of the sediment particles. The chemical properties of Be strongly suggest that ${ }^{10} \mathrm{Be}$ must essentially be completely removed from the sediments in a $6 \mathrm{M} \mathrm{HCl} \mathrm{leach} \mathrm{unless} \mathrm{some} \mathrm{very} \mathrm{refractory} \mathrm{phases} \mathrm{such} \mathrm{as}$ phosphates were formed during diagenesis within the sediment column. It is, however, unlikely that such phases formed in the Neogene section of the ACEX sediments because the amount of organic carbon supplied has always been very low during this period of time. In fact, as evident from studies reconstructing the past $\mathrm{Nd}$ and $\mathrm{Pb}$ isotope composition of Arctic bottom waters from early diagenetic $\mathrm{Mn}-\mathrm{Fe}$ coatings of the sediment particles [Haley et al., 2008a, 2008b], these Arctic Ocean sediments of the Lomonosov Ridge are very reliable archives for authigenic metals, including $\mathrm{Be}$, because the low organic carbon deposition allowed the presence of oxygen in the entire Neogene sediment section.

[16] The applied leaching method has been used in numerous other studies [e.g., Eisenhauer et al., 1994; Frank et al., 1997, 2000; Christl et al., 2003, 2007], in which marine sediments were successfully leached in order to work with the ${ }^{10} \mathrm{Be}$ as tracer for marine processes or as tracer for past magnetic field intensity. In particular, Frank et al. [2000] using the above leaching method, combined their data with complete dissolution data from the same area [Kumar et al., 1995], which gave consistent results. In fact it 


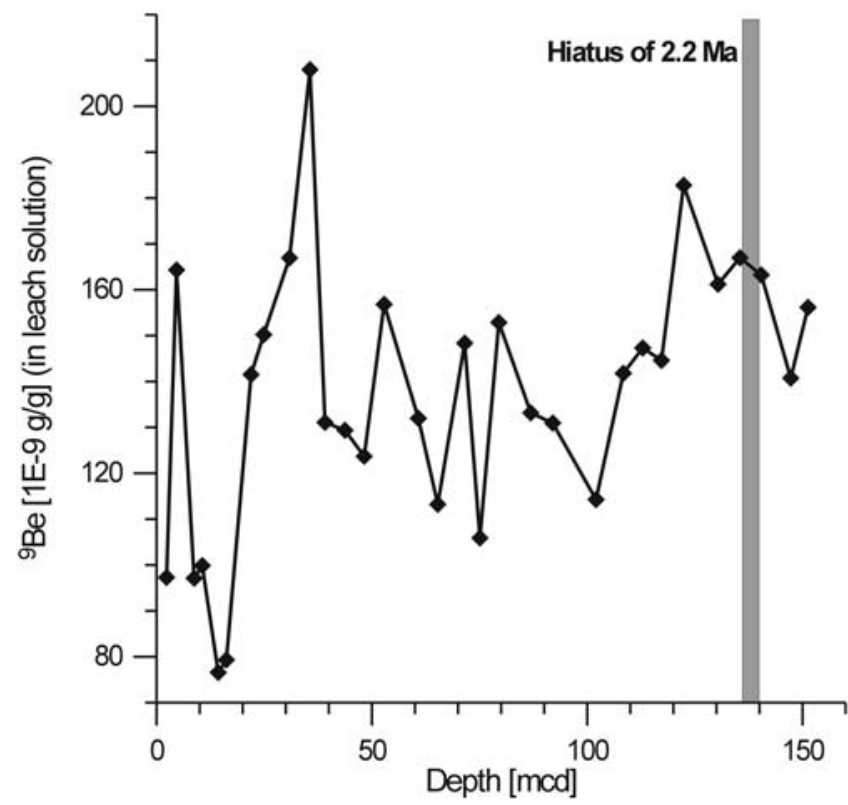

Figure 4. Leached ${ }^{9} \mathrm{Be}$ concentrations in ppb against depth in the ACEX core (mcd).

was even possible to spot a spike calibration problem by comparing the two data sets [Frank et al., 2000]. This suggests that the amount of ${ }^{10} \mathrm{Be}$ that was not removed by the leaching method from these Southern Ocean sediments must have been small.

[17] It cannot be completely excluded that a certain fraction of the ${ }^{10} \mathrm{Be}$ is not released from other sediments applying our method, which, however, is not expected to influence the reliability of the developed chronostratigraphy of the ACEX sediments. Given that the sediment composition that did not vary to a large extent, as described above, it is not expected that the fraction of released ${ }^{10} \mathrm{Be}$ changed throughout the core. In fact, there is only one unlikely case, how the average sedimentation rates estimated from the decrease of the ${ }^{10} \mathrm{Be}$ data, could have been altered by an incomplete release of ${ }^{10} \mathrm{Be}$ from the sediments: The ${ }^{10} \mathrm{Be}$ released from the sediments must have systematically and continuously increased or decreased with depth in core to mimic an exponential decrease. This is by all means extremely unlikely but if it indeed happened a coinciding systematic change in authigenic ${ }^{9} \mathrm{Be}$ concentrations would have to be observable as well, given that both $\mathrm{Be}$ isotopes behave chemically identical once deposited in the sediments. This is not the case (see below). In addition, the potential influence of diagenetic fronts would be reflected in simultaneous well-defined step changes of the concentrations of both $\mathrm{Be}$ isotopes, which are also not observed (see Figures 3 and 4).

[18] In order to further constrain the causes for the occurrence of the ${ }^{10} \mathrm{Be}$ peaks and to remove scatter of the down-core decrease, the ${ }^{10} \mathrm{Be}$ concentrations were normalized to the authigenic ${ }^{9} \mathrm{Be}$ concentrations obtained on the same samples (Figure 4). The ${ }^{9} \mathrm{Be}$ data do not show a large variability (roughly a factor of 2 in total) but overall lower values around $80-90 \mathrm{ppb}(1 \mathrm{E}-9 \mathrm{~g} / \mathrm{g}$; note that this is not an absolute concentration but only the Be content in the leach solution) are observed in the uppermost $20 \mathrm{~m}$ of the sediments, only interrupted by a higher value of $165 \mathrm{ppb}$ at 4.64 mcd. Below 20 med the ${ }^{9} \mathrm{Be}$ concentrations are generally higher (between 120 and $170 \mathrm{ppb}$ ) with a peak at $35.6 \mathrm{mcd}$. Comparison of the ${ }^{10} \mathrm{Be}$ and ${ }^{9} \mathrm{Be}$ concentrations shows that the ${ }^{10} \mathrm{Be}$ maximum at $4.64 \mathrm{mcd}$ coincides with an average ${ }^{9} \mathrm{Be}$ concentration. This does not point to a diminished sedimentation rate, which is not surprising in view of the fact that this sample is from a section containing increased amounts of coarse grained material (glacial conditions). The correlation of the exponential fit with the ${ }^{10} \mathrm{Be} /{ }^{9} \mathrm{Be}$ ratio (Figure 5) including all data above $135.5 \mathrm{mcd}$ is improved compared with that to the ${ }^{10} \mathrm{Be}$ concentrations $\left(\mathrm{r}^{2}=0.94\right)$, which is mainly caused by the reduction, but not the removal of the maximum at $4.64 \mathrm{~m}$ depth. The resulting average sedimentation rate is $14.5 \mathrm{~m} / \mathrm{Ma}$. Excluding the three maxima described above, gives an improved fit $\left(\mathrm{r}^{2}=\right.$ 0.97 ) but exactly the same sedimentation rate. We therefore adopted this sedimentation rate of $14.5 \mathrm{~m} / \mathrm{Ma}$ for establishing the chronostratigraphy of the ACEX core in the uppermost $151.3 \mathrm{~m}$. This results in an age of $9.4 \mathrm{Ma}$ at $135.5 \mathrm{~m}$ depth above the hiatus, 11.6 Ma below the hiatus at 140.4 $\mathrm{mcd}$, and $12.3 \mathrm{Ma}$ at $151.3 \mathrm{mcd}$. We infer that the age estimate down to $151.3 \mathrm{~m}$ is reliable to within $\pm 1 \mathrm{Ma}$, an

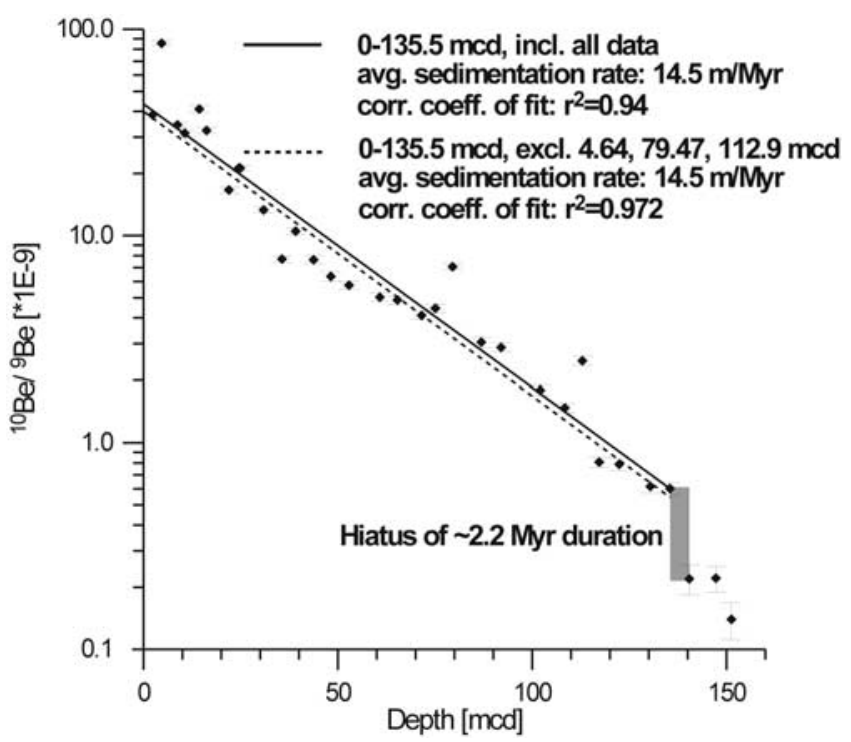

Figure 5. The ${ }^{10} \mathrm{Be} /{ }^{9} \mathrm{Be}\left(\times 10^{-9}\right)$ against depth in the ACEX core (mcd). Error bars are a combination of the $1 \sigma$ statistical uncertainties of the AMS ${ }^{10} \mathrm{Be}$-measurements and an approximate $1 \sigma$ error of the ${ }^{9} \mathrm{Be}$ measurements of $5 \%$. The solid line represents an exponential fit to all data of the upper $135.5 \mathrm{~m}$, whereas the dashed line represents a fit excluding significantly higher values at $4.64,79.47$, and 112.9 mcd. The correlation coefficients $\left(r^{2}\right)$ are 0.94 and 0.972 , respectively. The average sedimentation rate of $14.5 \mathrm{~m} / \mathrm{Ma}$ obtained by the two fits is identical and was applied for dating the ACEX core. The grey bar between 135.5 and $140.4 \mathrm{mcd}$ indicates the presence of a hiatus of about 2.2 Ma duration. 
a)

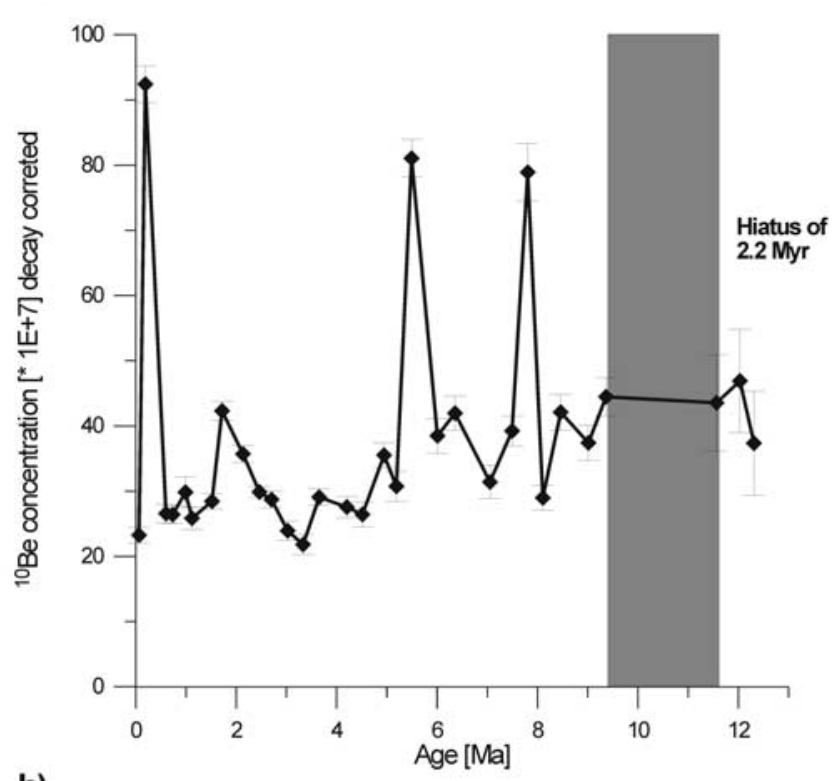

b)

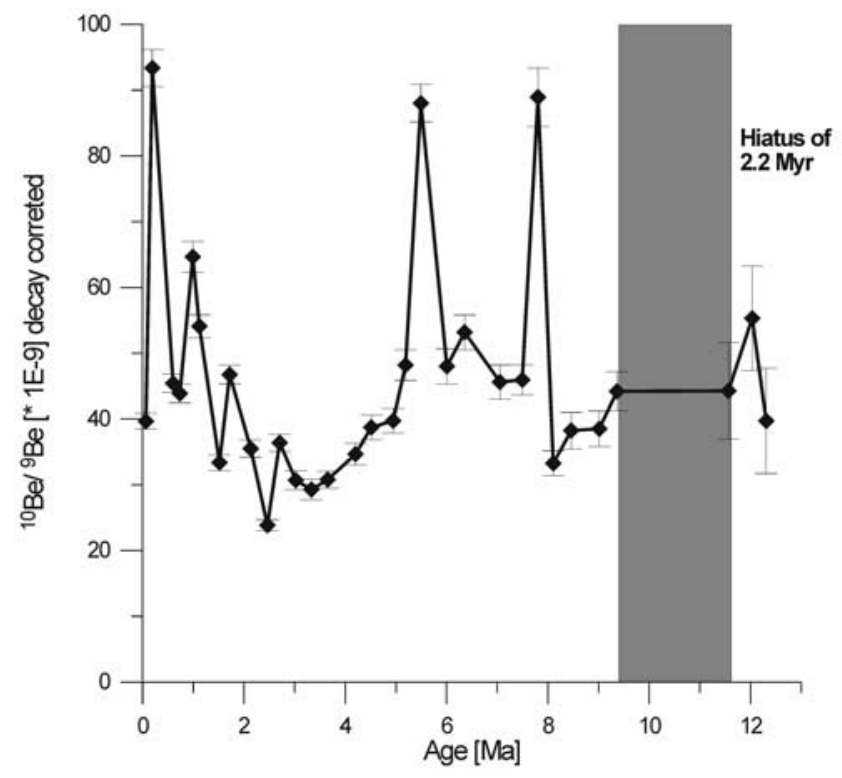

Figure 6. Decay corrected (initial) (a) ${ }^{10} \mathrm{Be}$ concentrations $\left(\times 10^{7}\right.$ atoms $\left./ \mathrm{g}\right)$ and $(\mathrm{b}){ }^{10} \mathrm{Be} /{ }^{9} \mathrm{Be}\left(\times 10^{-9}\right)$ against age in the ACEX core obtained by applying a sedimentation rate of $14.5 \mathrm{~m} / \mathrm{Ma}$ (Figure 5) and including a hiatus of $2.2 \mathrm{Ma}$ duration between 135.5 and 140.4 mod.

uncertainty mainly caused by the remaining scatter of the data and the uncertainty of the 1.51 million year half-life of ${ }^{10} \mathrm{Be}$ if we only include the uncertainty given by Hofmann et al. [1987]. The inferred average sedimentation rate is in good agreement with the few biostratigraphic markers available (mainly dinoflagellate cysts) and serves as the basis for the Neogene stratigraphy of the ACEX record (see Backman et al. [2008] for more details).
[19] On the basis of the chronostratigraphy obtained, ${ }^{10} \mathrm{Be}$ concentrations and ${ }^{10} \mathrm{Be} /{ }^{9} \mathrm{Be}$ are corrected for decay (Figure 6). The overall variability of the data besides the peaks is relatively small. The initial ${ }^{10} \mathrm{Be}$ concentrations of the three pronounced maxima range between 80 and $92 \times$ $10^{7} \mathrm{at} / \mathrm{g}$, which is similar to interglacial values found in Late Quaternary central Arctic cores [Spielhagen et al., 1997, 2004; Nowaczyk et al., 2001]. The uppermost sample at $2.31 \mathrm{mcd}$ and the youngest of the three maxima at $4.64 \mathrm{mcd}$ are located in a section of the ACEX core that cannot be dated by simple application of the average sedimentation rate of $14.5 \mathrm{~m} / \mathrm{Ma}$. A detailed stratigraphic correlation of lithological and physical parameters to the well-dated cores PS-2185 and 96-12-PC on the Lomonosov Ridge was carried out instead [O'Regan et al., 2008], because in the upper $5 \mathrm{~m}$ of the sediment cover, the sedimentation rates were certainly not constant in view of the large changes in grain size and ${ }^{10} \mathrm{Be}$ concentrations in the previously studied cores [Spielhagen et al., 1997, 2004; Jakobsson et al., 2001]. The uppermost sample is therefore placed in the middle of MIS 4 at $65 \mathrm{ka}$, which has an uncertainty not larger than $\pm 5 \mathrm{ka}$ constrained by the duration of MIS 4. The ${ }^{10} \mathrm{Be}$ peak at $4.64 \mathrm{mcd}$ falls into the very beginning of the pronounced 'glacial' period that corresponds to MIS 6 and an age of $\sim 185 \mathrm{ka}$ is assigned. Given that the sample is clearly from the very beginning of MIS 6 , this age is quite narrowly constrained $( \pm 5 \mathrm{ka}$, given that it cannot be older than $190 \mathrm{ka}$ ). The ages of the two other deeper maxima are 5.5 Ma and 7.8 Ma.

\subsection{Influence of Variations of Past Magnetic Field Intensity}

[20] Changes in ${ }^{10} \mathrm{Be}$ production rate may have altered the ${ }^{10} \mathrm{Be}$ deposition rates between factors of 0.8 and 2.2 times the modern value [Lal and Peters, 1967; Masarik and Beer, 1999]. Previous studies have demonstrated from various archives such as marine sediments, coral cores, and ice cores that maxima in global cosmogenic nuclide production on the 1000-year timescale corresponded to minima in the intensity of the geomagnetic dipole field of the Earth [e.g., Frank et al., 1997; Bard, 1998; Baumgartner et al., 1998; Christl et al., 2003]. The peaks in ${ }^{10} \mathrm{Be}$ deposition may thus have been caused by minima in geomagnetic field intensity. It has recently been shown that the ${ }^{10} \mathrm{Be}$ production signal related to geomagnetic excursions is recorded without offsets in high sedimentation rate locations, whereas in low sedimentation rate environments, such as the central Arctic Ocean, there are lags between the ${ }^{10} \mathrm{Be}$ and paleointensity signals caused by the residence time of ${ }^{10} \mathrm{Be}$ and the lockin-depth of the magnetic signal [McHargue and Donahue, 2005; Knudsen et al., 2008]. For the ACEX sediments a discontinuous record of magnetic field intensity is available (J. King et al., manuscript in preparation, 2008). The acquisition of a reliable paleointensity record at such high latitudes is not trivial owing to steep field lines and potential changes in magnetic mineral composition. In addition, there is also evidence that as yet unidentified postdepositional diagenetic processes, most likely not linked to redox- driven by oxygen consumption given the very low organic carbon input and content, were active, which affected both the 
a)

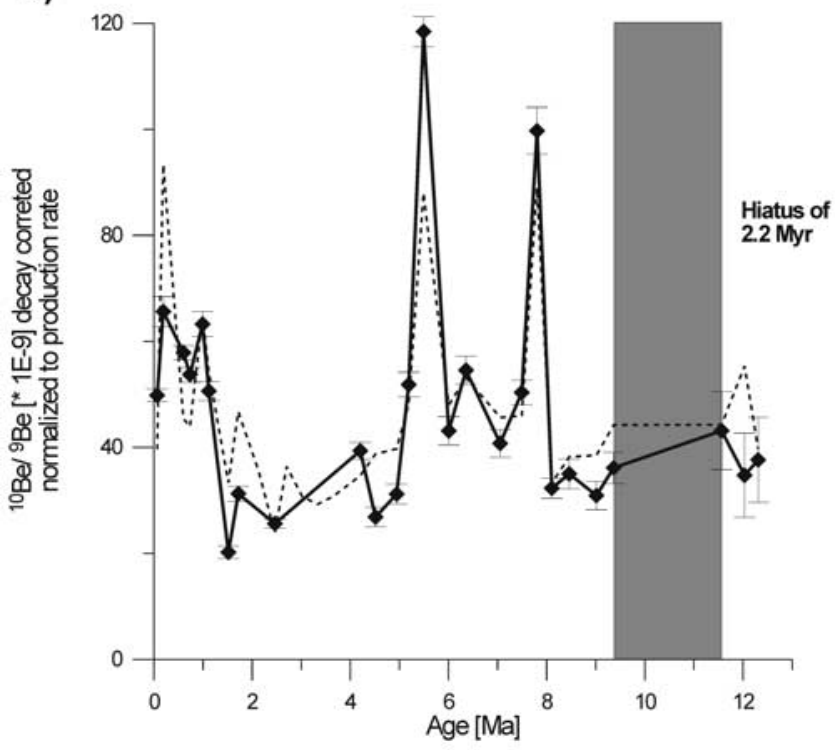

b)

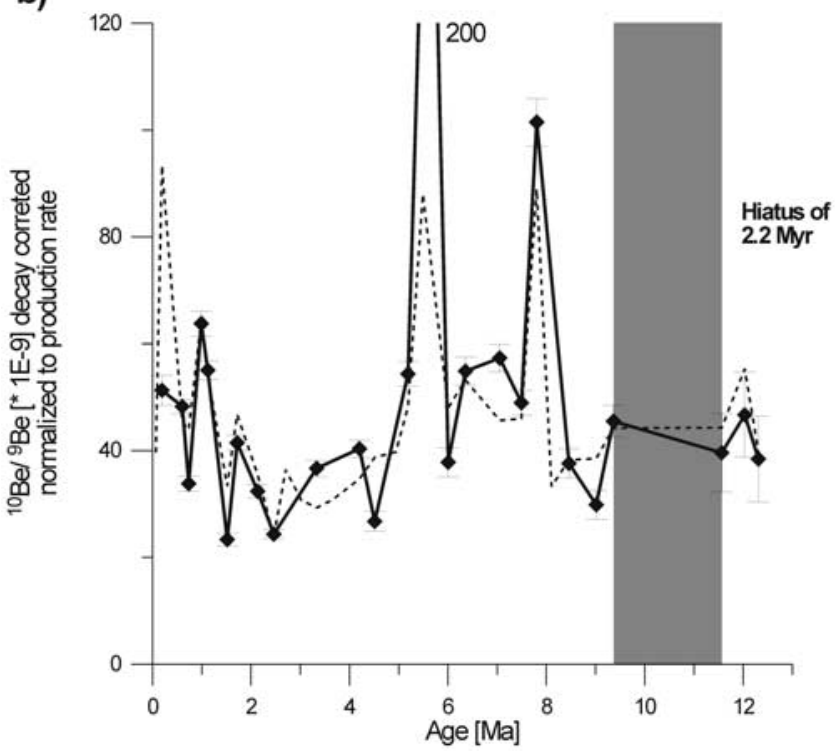

Figure 7. Initial ${ }^{10} \mathrm{Be} /{ }^{9} \mathrm{Be}\left(\times 10^{-9}\right)$ corrected for changes in ${ }^{10} \mathrm{Be}$ production rate following (a) case a and (b) case $b$ described in the text against age in the ACEX core (solid line). The dashed line plot denotes the initial ${ }^{10} \mathrm{Be} /{ }^{9} \mathrm{Be}$ values prior to correction for production rate changes (Figure 6b).

direction and intensity derived from the magnetic signal (J. King et al., manuscript in preparation, 2008). This is evident in some unrealistically high peaks in the field intensity record as well as some clear steps in the raw magnetic signals. We have nevertheless tried to estimate the influence of ${ }^{10} \mathrm{Be}$ production rate changes in our record by internally normalizing the available NRM/ARM values to achieve a relative paleointensity record that can be used to calculate production rate-corrected ${ }^{10} \mathrm{Be}$ concentrations and ${ }^{10} \mathrm{Be} /{ }^{9} \mathrm{Be}$. In order to account for the effects of lock-in-depth, which is clearly important in view of the large variability of the paleointensity patterns over short distances in the core, we calculated average paleointensity values (case a) from $2 \mathrm{~cm}$ above to $10 \mathrm{~cm}$ below each ${ }^{10} \mathrm{Be}$ data point, (case b) from the depth of the ${ }^{10} \mathrm{Be}$ data point to $25 \mathrm{~cm}$ below, and (case c) between 10 to $15 \mathrm{~cm}$ below each ${ }^{10} \mathrm{Be}$ data point. These were translated into relative production rate changes of ${ }^{10} \mathrm{Be}$ following the relationship of Masarik and Beer [1999] and were then used as correction factors for each ${ }^{10} \mathrm{Be} /{ }^{9} \mathrm{Be}$ value.

[21] The corrected data show a slight increase in scatter from an exponential decrease of the ${ }^{10} \mathrm{Be} /{ }^{9} \mathrm{Be}$ values with depth. This is illustrated by the lower correlation coefficients for cases a, $\mathrm{r}^{2}=0.92$; case $\mathrm{b}, \mathrm{r}^{2}=0.88$; and case $\mathrm{c}$, $r^{2}=0.94$. The estimates for the average sedimentation rates have remained within error the same as prior to the correction (case a, $14.2 \mathrm{~m} / \mathrm{Ma}$; case b, $15.4 \mathrm{~m} / \mathrm{Ma}$; and case $\mathrm{c}$, $14.9 \mathrm{~m} / \mathrm{Ma})$. This either suggests that production rate variations did not cause the scatter of the ${ }^{10} \mathrm{Be}$ data or that the uncertainties introduced by the quality of the paleointensity data and by the unknown lock-in-depth of the paleointensity signal in the low sedimentation rate ACEX core are too large to achieve a reliable correction for production rate changes. We will therefore stick to the sedimentation rate obtained from the non-production rate corrected ${ }^{10} \mathrm{Be} /{ }^{9} \mathrm{Be}$ data. Despite these uncertainties, the correction should remove the three large ${ }^{10} \mathrm{Be}$ maxima if they were indeed caused by a peak in ${ }^{10} \mathrm{Be}$ production rate. In Figure 7 the production corrected initial ${ }^{10} \mathrm{Be} /{ }^{9} \mathrm{Be}$ values are plotted versus age for cases a and b (case c looks very similar to case a and is therefore not included in Figure 7). It is immediately obvious that the production correction substantially decreased or even removed the ${ }^{10} \mathrm{Be} /{ }^{9} \mathrm{Be}$ peak at $4.64 \mathrm{mcd}$ corresponding to an age of $185 \pm 5 \mathrm{ka}$. Despite the fact that these corrections cannot be considered quantitative, the size and timing of the peak strongly suggest that the ${ }^{10} \mathrm{Be}$ peak corresponds to the pronounced Iceland Basin magnetic excursion, which occurred between 186 and $189 \mathrm{ka}$ [Channell et al., 1997; Channell, 1999; Knudsen et al., 2006] and which has also been observed in numerous records of ${ }^{10} \mathrm{Be}$ deposition [e.g., Frank et al., 1997; Knudsen et al., 2008]. The other two ${ }^{10} \mathrm{Be}$ maxima corresponding to ages of 5.5 and $7.8 \mathrm{Ma}$ are not removed by the production rate correction, which suggests that they must have been caused by a different process, most likely reduced sea ice cover during warmer periods enabling increased ${ }^{10} \mathrm{Be}$ fluxes to the seafloor.

\subsection{Implications for the Evolution of Arctic Sea Ice Cover and Climate}

[22] Only for two down-core samples the ${ }^{10} \mathrm{Be}$ concentrations were elevated to levels comparable to interglacial values recorded in other sediment cores from the Lomonosov Ridge (the sample at $185 \mathrm{ka}$ was most likely caused by increased ${ }^{10} \mathrm{Be}$ production, as described above). This suggests that the conditions for ${ }^{10} \mathrm{Be}$ deposition recorded by the ACEX sediments were only rarely similar to the last two interglacial periods over the past $12.3 \mathrm{Ma}$. Owing to our coarse sample resolution, however, it may be that other short periods of elevated ${ }^{10} \mathrm{Be}$ input occurred that we missed. In contrast, the ${ }^{10} \mathrm{Be}$ deposition rate, which is a 
combination of continental and atmospheric inputs into the surface ocean, remained at low levels, most likely predominantly controlled by a continuous sea ice cover [see also Darby et al., 2008; Krylov et al., 2008]. This is confirmed by calculating an average ${ }^{10} \mathrm{Be}$ flux into the sediments for the past $12.3 \mathrm{Ma}$. Applying an average ${ }^{10} \mathrm{Be}$ concentration of $38 \times 10^{7} \mathrm{at} / \mathrm{g}$ and a dry bulk density between 1.2 and 1.3 $\mathrm{g} / \mathrm{cm}^{3}$ [Backman et al., 2006], the average ${ }^{10} \mathrm{Be}$ flux into the sediments amounted to $0.6-0.7 \times 10^{9} \mathrm{at} / \mathrm{cm}^{2} \mathrm{ka}$ excluding the three maxima. This is at the lower end of global production rate estimates (see section 1) and agrees with the modeled low ${ }^{10} \mathrm{Be}$ deposition rates in high latitudes [Field et al., 2006]. It also agrees well with previous estimates of glacial ${ }^{10} \mathrm{Be}$ deposition rates in the Arctic Ocean [Eisenhauer et al., 1994; Spielhagen et al., 2004]. For this comparison it also needs to be taken into account that the intensity of the Earth's magnetic field was on average lower by $32 \%$ during the past $5 \mathrm{Ma}$ and even lower by about $50 \%$ for the period between 5 and $160 \mathrm{Ma}$ [Juarez and Tauxe, 2000]. This resulted in ${ }^{10} \mathrm{Be}$ production rates which were higher by $15-25 \%$ for this period of time and suggests that the ${ }^{10} \mathrm{Be}$ flux arriving at the Arctic sediments was even more than a factor of 2 lower than today for most of the past $12.3 \mathrm{Ma}$. Similarly low ${ }^{10} \mathrm{Be}$ fluxes have been interpreted as a consequence of efficient ${ }^{10} \mathrm{Be}$ export to the North Atlantic via sea ice and are consistent with the interpretation of a largely sea-ice covered Arctic Ocean over the past $12.3 \mathrm{Ma}$. The peaks in ${ }^{10} \mathrm{Be}$ deposition are consequently ascribed to relatively short periods of warmer climate conditions, during which a diminished sea ice cover allowed larger fluxes of ${ }^{10} \mathrm{Be}$ not only originating from the atmosphere but also from riverine inputs to arrive at the sediments of the Arctic Ocean.

[23] In contrast to the existence of at least two marked peaks, there is no indication for extreme minima caused by dilution events of the ${ }^{10} \mathrm{Be}$ concentrations by IRD to concentrations of $1 \times 10^{7} \mathrm{at} / \mathrm{g}$ or even below detection limits. These events are only observed for parts of the most recent two glacial periods in the uppermost $3 \mathrm{~m}$ of other Late Quaternary sediment cores from the Lomonosov Ridge [Spielhagen et al., 1997, 2004; Jakobsson et al., 2000]. In accordance with these previous studies, this clearly suggests that the sedimentary processes and underlying climatic conditions prevailing during the past $200 \mathrm{ka}$ were substantially different compared with the entire Neogene between $16 \mathrm{Ma}$ and $200 \mathrm{ka}$. This is remarkable in view of the fact that major global cooling started at about $14 \mathrm{Ma}$ and that the major onset of Northern Hemisphere Glaciation started at 2.7 $\mathrm{Ma}$ and there is no reason to assume that the conditions were substantially different prior to $200 \mathrm{ka}$, at least for the past 2.7 Ma. Apparently land-based ice sheets on Siberia, Canada and Greenland or grounded ice shelves in Siberia prior to about $200 \mathrm{ka}$ did not supply as much coarse grained IRD to the centre of the Arctic Ocean as thereafter, the reason of which remains elusive. The QUEEN project reconstructions of the Barents-Kara ice sheet suggest that the ice sheet of MIS 6 was the largest during the Quaternary in this area, which extended to the shelf edge [Svendsen et al., 2004]. The extensive ice erosion on the central Lomonosov Ridge has been attributed to this ice sheet [Jakobsson et al., 2001]. Mapped glaciogenic features, i.e., flutes and megascale glacial lineations, on the Lomonosov Ridge and Chukchi Borderland suggest that thick ice shelves were a prominent component of the MIS 6 glaciation [Jakobsson et al., 2008], but it is unclear why similarly large ice sheets did not exist prior to MIS 6, as suggested by the ACEX record.

\section{Conclusions}

[24] The exponential decrease of the ${ }^{10} \mathrm{Be} /{ }^{9} \mathrm{Be}$ data with depth obtained in this study allows the establishment of a chronostratigraphy of the ACEX cores for the past $12.3 \mathrm{Ma}$, which is in agreement with the few available biostratigraphic constraints, mainly dinoflagellate cysts [Backman et al., 2008]. The average sedimentation rate inferred from the ${ }^{10} \mathrm{Be} /{ }^{9} \mathrm{Be}$ data is $14.5 \mathrm{~m} / \mathrm{Ma}$, for which an uncertainty of \pm 1 $\mathrm{m} / \mathrm{Ma}$ is estimated. This rate further corroborates that sedimentation rates on the Lomonosov Ridge of the Arctic Ocean have not been lower than in pelagic sedimentation regimes of other ocean basins. A step in the ${ }^{10} \mathrm{Be}$ data between 135 and $140 \mathrm{mcd}$ indicates the presence of a previously unidentified hiatus of about $2.2 \mathrm{Ma}$ duration. The age-corrected data and average ${ }^{10} \mathrm{Be}$ fluxes indicate a largely stable depositional regime under a continuous sea ice cover for most of the past $12.3 \mathrm{Ma}$, which was similar to glacial conditions of the Late Quaternary, although extreme dilution events with coarse grained IRD from the surrounding continental landmasses such as during the glacial periods of the past $200 \mathrm{ka}$ are not observed in the Neogene ${ }^{10} \mathrm{Be}$ record. Three pronounced peaks of ${ }^{10} \mathrm{Be}$ concentrations and ${ }^{10} \mathrm{Be} /{ }^{9} \mathrm{Be}$, which are similar in amplitude to expected interglacial values, occurred at $\sim 185 \mathrm{ka}, 5.5 \mathrm{Ma}$ and $7.8 \mathrm{Ma}$. While the youngest peak was most likely caused by an increase in ${ }^{10} \mathrm{Be}$ production rate during the Iceland Basin geomagnetic excursion, the two older ones are ascribed to short warmer periods with diminished sea ice cover, which allowed increased amounts of ${ }^{10} \mathrm{Be}$ to reach the sediments of the Arctic Ocean.

[25] Acknowledgments. The ACEX sediments were acquired through joint efforts of the IODP, ECORD, and the Swedish Polar Research Secretariat. Jutta Heinze is thanked for smooth chemical preparations, Ulrike Westernströer at the IfG Kiel is thanked for measurements of the ${ }^{9}$ Be concentrations, and Fabian Scheifele at ETH Zurich helped with the final preparations of the ${ }^{10} \mathrm{Be}$ samples for the AMS measurements. The analysis of the ${ }^{10} \mathrm{Be}$ concentrations was performed at the Zurich AMS Facility jointly operated by the Swiss Federal Institute of Technology, Zurich, and Paul Scherrer Institut, Villigen, Switzerland.

\section{References}

Aldahan, A., and G. Possnert (2000), The ${ }^{10} \mathrm{Be}$ marine record of the last $3.5 \mathrm{Ma}, \mathrm{Nucl}$. Instrum. Methods Phys. Res., Sect. B, 172, $513-517$.
Aldahan, A., S. Ning, G. Possnert, J. Backman, and K. Boström (1997), ${ }^{10} \mathrm{Be}$ records from sediments of the Arctic Ocean covering the past 350 ka, Mar. Geol., 144, 147-162.
Anderson, R. F., Y. Lao, W. S. Broecker, S. E. Trumbore, H. J. Hofmann, and W. Wölfli (1990), Boundary scavenging in the Pacific 
Ocean: A comparison of ${ }^{10} \mathrm{Be}$ and ${ }^{231} \mathrm{~Pa}$, Earth Planet. Sci. Lett., 96, 287-304.

Backman, J., M. Jakobsson, J. Knies, J. O. Knutsen, Y. Kristoffersen, A. Lif, E. Musatov, and R. Stein (1997), Geological coring and high resolution chirp sonar profiling: Swedish Polar Research Secretariat, in Polarforskningssekritariatets årsbok 1995/96, edited by E. Grönlund, pp. 64-66, Swed. Polar Res. Secr., Stockholm.

Backman, J., M. Jakobsson, R. Løvlie, L. Polyak, and L. A. Febo (2004), Is the central Arctic Ocean a sediment starved basin?, Quat. Sci. Rev., 23, 1435-1454.

Backman, J., K. Moran, D. B. McInroy, and L. A. Mayer (2006), Ocean Drilling Program 203, Proc. Integrated Ocean Drill. Program, 302, doi:10.2204/iodp.proc.302.

Backman, J., et al. (2008), Age model and coreseismic intergration for the Cenozoic ACEX sediments from the Lomonosov Ridge, Paleoceanography, doi:10.1029/2007PA001476, in press.

Bard, E. (1998), Geochemical and geophysical implications of the radiocarbon calibration, Geochim. Cosmochim. Acta, 62, 2025-2038.

Baumgartner, S., J. Beer, J. Masarik, G. Wagner, L. Meynadier, and H. A. Synal (1998), Geomagnetic modulation of the Cl-36 flux in the GRIP ice core, Greenland, Science, 279, $1330-1332$.

Bayon, G., C. R. German, R. M. Boella, J. A. Milton, R. N. Taylor, and R. W. Nesbitt (2002), An improved method for extracting marine sediment fractions and its application to $\mathrm{Sr}$ and $\mathrm{Nd}$ isotopic analysis, Chem. Geol., 187, 179-199.

Bourlès, D., G. M. Raisbeck, and F. Yiou (1989), ${ }^{10} \mathrm{Be}$ and ${ }^{9} \mathrm{Be}$ in marine sediments and their potential for dating, Geochim. Cosmochim. Acta, 53, 443-452.

Brown, T. A., D. E. Nelson, J. R. Southon, and J. S. Vogel (1987), ${ }^{10} \mathrm{Be}$ production rate variations as recorded in a mid latitude lake sediment, Nucl. Instrum. Methods Phys. Res., Sect. B, 29, 232-237.

Channell, J. E. T. (1999), Geomagnetic paleointensity and directional secular variation at Ocean Drilling Program (ODP) Site 984 (Bjorn Drift) since $500 \mathrm{ka}$ : comparisons with ODP Site 983 (Gardar Drift), J. Geophys. Res., 104, 22,937-22,951.

Channell, J. E. T., D. A. Hodell, and B. Lehman (1997), Relative paleomagnetic intensity and $\delta^{18} \mathrm{O}$, Earth Planet. Sci. Lett., 153, 103-118.

Christl, M., C. Strobl, and A. Mangini (2003), Beryllium-10 in deep-sea sediments: A tracer for the Earth's magnetic field intensity during the last 200,000 years, Quat. Sci. Rev., 22, $725-739$

Christl, M., A. Mangini, and P. W. Kubik (2007), Highly resolved Beryllium-10 record from ODP Site 1089-A global signal?, Earth Planet. Sci. Lett., 257, 245-258.

Darby, D. A. (2008), Arctic perennial ice cover over the last 14 million years, Paleoceanography, 23, PA1S07, doi:10.1029/2007PA001479.

Darby, D. A., L. Polyak, and H. Bauch (2006), Past glacial and interglacial conditions in the Arctic Ocean and marginal seas-A review, Prog. Oceanogr., 71, 129-144.

Delagnese, D. J., and D. L. Clark (1994), Siliceous microfossils from the warm Late Cretaceous and early Cenozoic Arctic Ocean, J. Paleontol., 68, 31-47.

Eisenhauer, A., R. F. Spielhagen, M. Frank, G. Hentzschel, A. Mangini, P. W. Kubik, B. Dittrich-Hannen, and T. Billen (1994),
${ }^{10} \mathrm{Be}$ records of sediment cores from high northern latitudes: Implications for environmental and climatic changes, Earth Planet. Sci. Lett., 124, 171-184.

Field, C. V., G. A. Schmidt, D. Koch, and C. Salyk (2006), Modeling production and climate-related impacts on ${ }^{10} \mathrm{Be}$ concentration in ice cores, J. Geophys. Res., 111, D15107, doi:10.1029/ 2005JD006410.

Fink, D., and A. Smith (2007), An inter-comparison of ${ }^{10} \mathrm{Be}$ and ${ }^{26} \mathrm{Al}$ AMS reference standards and the ${ }^{10} \mathrm{Be}$ half-life, Nucl. Instrum. Methods Phys. Res., Sect. B, 259, 600-609.

Frank, M., J.-D. Eckhardt, A. Eisenhauer, P. W Kubik, B. Dittrich-Hannen, and A. Mangini (1994), ${ }^{10} \mathrm{Be},{ }^{230} \mathrm{Th}$ and ${ }^{231} \mathrm{~Pa}$ in Galapagos Microplate sediments: Implications for hydrothermal activity and paleoproductivity changes during the last 100,000 years, Paleoceanography, 9, 559-578.

Frank, M., B. Schwarz, S. Baumann, P. W. Kubik, M. Suter, and A. Mangini (1997) A $200 \mathrm{kyr}$ record of cosmogenic radionuclide production rate and geomagnetic field intensity from ${ }^{10} \mathrm{Be}$ in globally stacked deep-sea sediments, Earth Planet. Sci. Lett., $149,121-129$

Frank, M., R. Gersonde, M. M. Rutgers van der Loeff, G. Bohrmann, C. Nürnberg, P. W. Kubik, M. Suter, and A. Mangini (2000), Similar glacial and interglacial export bioproducivity in the Atlantic sector of the Southern Ocean: Multiproxy evidence and implications for atmospheric $\mathrm{CO}_{2}$, Paleoceanography, 15, 642-658.

Frank, M., M. M. Rutgers van der Loeff, P. W. Kubik, and A. Mangini (2002), Quasi-conservative behaviour of ${ }^{10} \mathrm{Be}$ in deep waters of the Weddell sea and the Atlantic sector of the Antarctic Circumpolar Current, Earth Planet. Sci. Lett., 201, 171-186.

Garbe-Schönberg, C. D. (1993), Simultaneous determination of 37 trace elements in 28 international rock standards by ICP-MS, Geostand. Newsl., 17, 81-93.

Gutjahr, M. H., M. Frank, C. H. Stirling, V. Klemm, T. van de Flierdt, and A. N. Halliday (2007), Reliable extraction of a deepwater race metal isotope signal from Fe-Mn oxy hydroxide coatings of marine sediments, Chem. Geol., 242, 351-370.

Haley, B. A., M. Frank, R. F. Spielhagen, and A. Eisenhauer (2008a), Influence of brine formation on Arctic Ocean circulation ove the past 15 million years, Nature Geosci. 1, 68-72.

Haley, B. A., M. Frank, R. F. Spielhagen, an J. Fietzke (2008b), Radiogenic isotope record of Arctic Ocean circulation and weathering inputs of the past 15 million years, Paleocea nography, doi:10.1029/2007PA001486, in press.

Henken-Mellies, W. U., J. Beer, F. Heller, K. J. Hsü, C. Shen, G. Bonani, H. J. Hofmann, M. Suter, and W. Wölfli (1990), ${ }^{10} \mathrm{Be}$ and ${ }^{9} \mathrm{Be}$ in South Atlantic DSDP site 519: Relation to geomagnetic reversals and to sediment composition, Earth Planet. Sci. Lett., 98, 267-276.

Hofmann, H. J., J. Beer, G. Bonani, H. R. von Gunten, S. Raman, M. Suter, R. L. Walker, W. Wölfli, and D. Zimmermann (1987), ${ }^{10} \mathrm{Be}$ : Half-life and AMS-standards, Nucl. Instrum. Methods Phys. Res., Sect. B, 29, 32-36.

Jakobsson, M., R. Løvlie, H. Al-Hanbali, E. M. Arnold, J. Backman, and M. Mörth (2000), Manganese and color cycles in the Arctic Ocean sediments constrain Pleistocene chronology, Geology, 28, 23-26.
Jakobsson, M., R. Løvlie, E. M. Arnold, J. Backman, L. Polyak, J.-O. Knutsen, and E. Musatov (2001), Pleistocene stratigraphy and paleoenvironmental variation from Lomonosov Ridge sediments, central Arctic Ocean, Global Planet. Change, 31, 1-22.

Jakobsson, M., L. Polyak, M. Edwards, and B. Coakley (2008), Glacial geomorphology of the central Arctic Ocean: Chukchi borderland and the Lomonosov Ridge, Earth Surf. Processes Landforms, in press.

Jenkyns, H. C., A. Forster, S. Schouten, and J. Sinninghe Damste (2004), High temperatures in the Late Cretaceous Arctic Ocean, Nature, 432, 888-892.

Juarez, M. T., and L. Tauxe (2000), The intensity of the time-averaged geomagnetic field: The last $5 \mathrm{Myr}$, Earth Planet. Sci. Lett., 175, $169-180$.

Knudsen, M. F., C. Mac Niocaill, and G. M. Henderson (2006), High-resolution data of the Iceland Basin geomagnetic excursion from ODP sites 1063 and 983: Existence of intense flux patches during the excursion?, Earth Planet. Sci. Lett., 251, 18-32.

Knudsen, M. F., G. M. Henderson, M. Frank, C. Mac Niocaill, and P. W. Kubik (2008), Inphase anomalies in Beryllium-10 production and palaeomagnetic field behaviour during the Iceland Basin geomagnetic excursion, Earth Planet. Sci. Lett., 265, 588-599.

Kristoffersen, Y., B. Coakley, W. Jokat, M. Edwards, H. Brekke, and J. Gjengedal (2004), Seabed erosion on the Lomonosov Ridge, central Arctic Ocean: A tale of deep draft icebergs in the Eurasia Basin and the influence of Atlantic water inflow on iceberg motion?, Paleoceanography, 19, PA3006, doi:10.1029/2003PA000985.

Krylov, A., I. Andreeva, C. Vogt, J. Backman, V. V. Krupskaya, G. E. Grikurov, K. Moran, and H. Shoji (2008), A shift in heavy and clay mineral provenance indicates a middle Miocene onset of a perennial sea ice cover in the Arctic Ocean, Paleoceanography, doi:10.1029/ 2007PA001497, in press.

Ku, T. L., M. Kusakabe, C. I. Measures, J. R. Southon, G. Cusimano, J. S. Vogel, D. E. Nelson, and S. Nakaya (1990), Beryllium isotope distribution in the western North Atlantic: A comparison to the Pacific, Deep Sea Res., 37, 795-808.

Kumar, N., R. F. Anderson, R. A. Mortlock, P. N. Froelich, P. W. Kubik, B. Dittrich-Hannen, and M. Suter (1995), Increased biological productivity and export production in the glacial Southern Ocean, Nature, 378, 675-680.

Kusakabe, M., T.-L. Ku, J. R. Southon, J. S Vogel, D. E. Nelson, C. I. Measures, and Y Nozaki (1987), Distribution of ${ }^{10} \mathrm{Be}$ and ${ }^{9} \mathrm{Be}$ in the Pacific Ocean, Earth Planet. Sci. Lett., 82 , 231-240.

Kusakabe, M., T.-L. Ku, J. R. Southon, and C. I. Measures (1990), Beryllium isotopes in the ocean, Geochem. J., 24, 263-272.

Kusakabe, M., T. L. Ku, J. R. Southon, S. Liu, J. S. Vogel, D. E. Nelson, S. Nakaya, and G. L. Cusinmano (1991), Be isotopes in rivers/ estuaries and their oceanic budgets, Earth Planet. Sci. Lett., 102, 265-276.

Lal, D. and B. Peters (1967), Cosmic ray produced radioactivity on the Earth, in Handbuch der Physik, vol. XLVI/2, pp. 551-612, Springer, Berlin.

Masarik, J., and J. Beer (1999), Simulation of particle fluxes and cosmogenic nuclide production in the Earth's atmosphere, J. Geophys. Res., 104, 12,099-12,111. 
McHargue, L. R, and D J. Donahue (2005), Effects of climate and the cosmic-ray flux on the ${ }^{10} \mathrm{Be}$ content of marine sediments, Earth Planet. Sci. Lett., 232, 193-207.

Measures, C. I., T.-L. Ku, S. Luo, J. R. Southon, X. Xu, and M. Kusakabe (1996), The distribution of ${ }^{10} \mathrm{Be}$ and ${ }^{9} \mathrm{Be}$ in the South Atlantic, Deep Sea Res., Part I, 43, 978-1009.

Monaghan, M., S. Krishnaswami, and K. K. Turekian (1985/1986), The global average production rate of ${ }^{10} \mathrm{Be}$, Earth Planet. Sci. Lett., 76, 279-287.

Moran, K., et al. (2006), The Cenozoic palaeoenvironment of the Arctic Ocean, Nature, 441, 601-605.

Nishiizumi, K., M. Imamura, M. W. Cafee, J. R. Southon, R. C. Finkel, and J. McAninch (2007), Absolute calibration of ${ }^{10} \mathrm{Be}$ AMS standards, Nucl. Instrum. Methods Phys. Res., Sect. B, 258, 403-413.

Nørgaard-Pedersen, N., R. F. Spielhagen, J. Thiede, and H. Kassens (1998), Central Arctic surface ocean environment during the past 80,000 years, Paleoceanography, 13, 193-204.

Nowaczyk, N., T. W. Frederichs, H. Kassens, N. Nørgaard-Pedersen, R. F. Spielhagen, R. Stein, and D. Weiel (2001), Sedimentation rates in the Makarov Basin, central Arctic Ocean: A paleomagnetic and rock magnetic approach, Paleoceanography, 16, 368-389.

O'Regan, M., J. King, J. Backman, M. Jakobsson, H. Pälike, K. Moran, C. Heil, T. Sakamoto, T. M. Cronin, and R. W. Jordan (2008), Constraints on the Pleistocene chronology of sediments from the Lomonosov Ridge, Paleoceanography, doi:10.1029/2007PA001551, in press.

Polyak, L., M. H. Edwards, B. J. Coakley, and M. Jakobsson (2001), Ice shelves in the Pleistocene Arctic Ocean inferred from glaciogenic deep sea bedforms, Nature, 410, 453-457.

Raisbeck, G. M., F. Yiou, M. Fruneau, M. Lieuvin and J. M. Loiseaux (1978), Measurement of ${ }^{10} \mathrm{Be}$ in 1,000-year-old and 5000-year-old Antarctic ice, Nature, 275, 731-733.

Schlosser, P., J. H. Swift, D. Lewis, and S. L. Pfirman (1995), The role of large scale Arctic Ocean circulation in the transport of contaminants, Deep Sea Res., Part II, 42, 1341-1367.

Sluijs, A., et al. (2006), Subtropical Arctic Ocean temperatures during the Paleocene/Eocene thermal maximum, Nature, 441, 610-613.

Somayajulu, B. L. K., P. Sharma, and W. H. Berger (1984), ${ }^{10} \mathrm{Be},{ }^{14} \mathrm{C}$, and U-Th decay series nuclides and $\delta^{18} \mathrm{O}$ in a box core from the central North Atlantic, Mar. Geol., 54, 169-180.

Spielhagen, R. F., et al. (1997), Arctic Ocean evidence for late Quaternary initiation of northern Eurasian ice sheets, Geology, 25, $783-786$.

Spielhagen, R. F., K.-H. Baumann, H. Erlenkeuser, N. R. Nowaczyk, N. Nørgaard-Pedersen, C. Vogt, and D. Weiel (2004), Arctic ocean deep-sea record of northern Eurasian ice sheet history, Quat. Sci. Rev., 23, 1455-1483.

Strobl, C., V. Schulz, S. Vogler, S. Baumann, H. Kassens, P. W. Kubik, M. Suter, and
A. Mangini (1999), Determination of depositional beryllium-10 fluxes in the area of the Laptev Sea and beryllium-10 concentrations in water samples of high northern latitudes, in Land-Ocean Systems in the Siberian Arctic: Dynamics and History, edited by H. Kassens et al., pp. 515-532, Springer, Berlin.

Svendsen, J. I., et al. (2004), Late quaternary ice sheet history of northern Eurasia, Quat. Sci. Rev., 23, 1229-1271.

J. Backman and M. Jakobsson, Department of Geology and Geochemistry, Stockholm University, Stockholm, SE-10691, Sweden.

M. Frank and B. A. Haley, IFM-GEOMAR, Leibniz Institute of Marine Sciences, Wischhofstrasse 1-3, D-24148 Kiel, Germany. (mfrank@ ifm-geomar.de)

D. Garbe-Schönberg, Institute of Geosciences, University of Kiel, Ludewig-Meyn-Straße 10, D-24118 Kiel, Germany.

J. King and M. O'Regan, Graduate School of Oceanography, University of Rhode Island, Narragansett, RI 02882, USA.

P. W. Kubik, Paul Scherrer Institute, Institute of Particle Physics, ETH-Zurich, CH-8093, Zurich, Switzerland.

K. Moran, Graduate School of Oceanography and Department of Ocean Engineering, University of Rhode Island, Narragansett, RI 02882, USA. 